\title{
Higher-Order Thinking Skills on Test Items Designed by English Teachers: A Content Analysis
}

\author{
Fajar Dwi Utami ${ }^{1}$, Joko Nurkamto ${ }^{2}$, Sri Marmanto ${ }^{3}$
}

\section{ARTICLE INFO}

Article History:

Received 23.04.2019

Received in revised form

04.10.2019

Accepted

Available online 01.12.2019

\begin{abstract}
In dealing with the demand for critical and creative thinking skills in the 21st-century, the Indonesia government has implemented 2013 curriculum which promotes higher-order thinking skills (HOTS) in the classroom. However, the implementation of HOTS-based curriculum gave impact to the way teacher assesses the students' thinking skills as they are expected to be able to design HOTS-based test items in assessing students. Accordingly, this study investigated the higher-order thinking skills represented on the test items designed by English teachers of Indonesia at the senior high school level. This study was conducted qualitatively by analyzing four sets of test items, gathered from a senior high school in Indonesia from 2016 to 2019, using Bloom's revised taxonomy. It was found that most questions were dominated by lower-order thinking skills, specifically understanding level, with the total percentage of more than $50 \%$ each set of test items. However, the higher-order thinking skill found in the test items is the only skill of analyzing while the skills of evaluating or creating were not covered. Thus, it is suggested that an evaluation is important to evaluate the test items made since the proportion of lower-order thinking skills as well as higher-order thinking skills are not proportional and whether those test items can be sufficient to promote higher-order thinking skills to the students.
\end{abstract}

(C) IJERE. All rights reserved

Keywords: ${ }^{1}$

Higher-order thinking skills, test items, bloom's revised taxonomy, english teaching

\section{INTRODUCTION}

In the $21^{\text {st }}$ century, globalization inevitably contributes to the rapid transformation of human life in all areas (Assare, Mohammadi, Forutan, \& Salehizadeh, 2016), one of the areas is education (Duman \& Karagoz, 2016). Education provides supports for individuals' social life (Asysyifa, Jumaidi, Wilujeng, \& Kuswanto, 2019) and nowadays it has become a more critical point in facing economic, environmental, and social challenges. Education should be able to prepare young generations to meet their adult roles in the future by developing a range of knowledge and skills. Those knowledge and skills are not limited to the mastery of subject matters and its application, but it should include the skills which are demanded by the $21^{\text {st-century }}$ life such as critical thinking, problem-solving, communication, collaboration, and self-management (Council, 2013). Besides, a set of competencies are also proposed in Partnership for 21st Century Skills (P21) (2015) which cover some competencies namely competency of critical thinking and problem solving, communication, collaboration, and creativity and innovation to empower young generations. From those skills and competencies demanded, the points of attention fall mainly in creative and critical thinking which are generally taught and infused to the daily activities of students including senior high school students. Critical thinking is a style of thinking that demonstrates cognitive processes such as reasoning, analyzing and evaluating(Akin et al., 2015). Based on Conklin (2012), creative thinking is a higher-order thinking skills that is characterized by inventing and synthesizing. In $21^{\text {st }}$ century, creative thinking is as important as critical thinking to be prepared. It is commonly believed that individuals' thinking skills can be formed by facilitating students to deal with problems that help them think critically with their rational thought (Mulyanto, Gunarhadi, \& Indriayu, 2018) . In addition, regarding the demand of the $21^{\text {st-century, the }}$ government of Indonesia realizes that creative and critical thinking are essential so that they design a curriculum that facilitates teachers to develop those skills in the classroom. The current curriculum applied in Indonesia is 2013 curriculum which emphasizes the implementation of Higher-Order Thinking skills to support the development of students' creative and critical thinking. The term HOTS has been widely used for decades in an educational context (Pogrow, 1988; Setyarini \& Ling, 2019; Zohar, 2006), but there are some various definitions of it. Lewis \& Smith (2009) stated that there is some bias in the definition of critical thinking, problem-solving, and creative thinking, so that they proposed a broader term called higher-order thinking skills (HOTS) which comprises some thinking skills including creative thinking. Nastasi and

\footnotetext{
Corresponding e-mail: fajarutami08@gmail.com, https://orcid.org/0000-0003-4731-7809

${ }^{2}$ https://orcid.org/0000-0002-8231-0779

${ }^{3}$ https://orcid.org/0000-0002-7198-5404

$1,2,3$ Sebelas Maret University, Surakarta, Indonesia
} 
Clements (1987) defined HOTS as skills that encompass the process of applying and evaluating while lowerorder thinking skills include the skills that involve the acquisition of knowledge and understanding knowledge. Conklin (2012) postulated that HOTS are skills that consist of both critical and creative thinking. Moreover, Anderson and Krathwohl (2001) stated that higher-order thinking skills (HOTS) are the skills involving the process of analyzing, evaluating, and creating. Thus, HOTS encompassing critical and creative thinking skills can be defined as skills that involve the process of analyzing, evaluating, and creating. In the implementation of HOTS, based on 2013 curriculum, teachers are guided by Bloom's revised taxonomy which helps them determine the objectives in the classroom. Bloom's revised taxonomy is the upgrade version of Bloom's taxonomy which is firstly proposed by Bloom. Originally, Bloom's taxonomy classifies some cognitive performances into six major which fall under the term lower-order thinking skills and higher-order thinking skills (Brookhart, 2010). It consists of knowledge, comprehension, application, analysis, synthesis, and evaluation. Furthermore, Anderson \& Krathwohl (2001) revised the cognitive process labeled from the noun forms to verb forms. The revised one encompasses some cognitive performances namely remembering, understanding, applying, analyzing, evaluating, and creating. In addition, the top skill in the taxonomy is revised as well where the creating process is placed number one on the taxonomy.

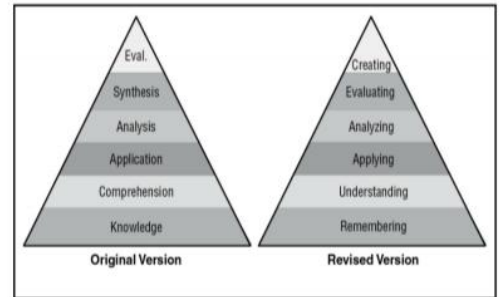

Figure 1. The original and revised version of Bloom's taxonomy (Conklin, 2012)

In the revised version, Anderson \& Krathwohl (2001) describe the aspects of thinking skills from lower-order thinking skills to higher-order thinking skills in the revised version taxonomy as follows. The first lowest cognitive level under the term lower-order thinking skills is remembering. It involves the ability to retrieve relevant knowledge from long-term memory. The second cognitive level under the term lowerorder thinking skills is the skill of understanding. It involves the ability to construct meaning from instructional messages including oral, written, and graphic communication. The last cognitive level under the term lower-order thinking skills is applying. It involves the ability to execute or implement a procedure to solve problems and apply knowledge to the actual situation. In addition, the cognitive levels under the term higher-order thinking skills are analyzing, evaluating and creating. Analyzing is the ability to break the material into its constituent parts and determine how the parts relate to another and overall structure or purpose. Evaluating is the ability that involves making a judgment based on particular criteria and standards. Creating is the ability to put elements together to form a coherent or functional whole, reorganize elements into a new pattern or structure.

A study conducted by Khan \& Inamullah (2011) reveals the level of questions given by teachers during the teaching process based on Bloom's cognitive taxonomy. The result shows that the ratio of LOT questions is higher than the HOTS ones. The result of the study is expected to stimulate teachers in improving their promoting HOTS in the classroom. Some studies on textbooks regarding HOTS and LOTS questions were also conducted in the recent decade by employing content analysis based on Bloom's taxonomy. Those studies show that the percentage of LOTS questions dominated (Anasy, 2016; Freahat \& Smadi, 2014; Igbaria, 2013; Raqqad \& Ismail, 2018; Razmjoo \& Kazempourfard, 2012; Ulum, 2016; Zaiturrahmi, Kasi, \& Zulfikar, 2017). Besides, studies on examination questions were conducted by Alzu'bi (2014) and Ahmad (2016). Alzu'bi (2014) administered a study aimed to evaluate English questions of Jordanian Secondary Certificate Examinations. The sample of the study was questions of the general secondary examination which then analyzed based on Bloom's cognitive taxonomy. The result shows that $69.6 \%$ of the questions were LOTS questions while the percentage of HOTS questions was $30.4 \%$ out of all. Ahmad (2016) examined LOTS and HOTS which were reflected on the English National Examination (ENE) items in the academic year of 2013/2014. The result showed that LOTS questions frequency was higher than HOTS questions frequency. In 2018, Ramadhana, Rozimela, and Fitrawati investigated HOTS, based on Bloom's taxonomy, represented on test items developed by English teachers of one of senior high schools in 
Padang, Indonesia. The test items analyzed were from grade XI in the academic year 2016/2017. It was found that $33 \%$ of HOTS-based questions were found in the Midterm test and $17 \%$ of HOTS questions were found in the semester test. Furthermore, the higher-order thinking skills which were mostly used on the questions were deducting and creating.

\section{Situation of the Problem}

There have been some studies investigated HOTS questions in textbooks, but only few investigated questions designed by English teachers (Anasy, 2016; Freahat \& Smadi, 2014; Igbaria, 2013; Raqqad \& Ismail, 2018; Razmjoo \& Kazempourfard, 2012; Ulum, 2016; Zaiturrahmi et al., 2017). It is important to analyze the test items designed by English teachers since it reflects the implementation of HOTS, as suggested by 2013 curriculum, in the area of assessment. Thus, the analysis of the test items can be done to support the curriculum and enrich the findings in this area.

\section{Aim of the Study}

Based on the problem presented, the present study aims to investigate higher-order thinking skills and lower-order thinking skills represented on English test items designed by English teachers by using Bloom's revised taxonomy. The results of the present study are expected to help English teacher as well as government to evaluate the implementation of HOTS, specifically in the area of students' assessment.

\section{METHOD}

The current study used a content analysis method to uncover the thinking skills on the questions designed by English teachers. Content analysis is qualitative research that focuses on analyzing and interpreting recorded material (Ary, Jacobs, Irvine, \& Walker, 2010). The form of the material may vary such as public records, textbooks, letters, films or other documents.

\section{Material}

In thie present study, the data employed were four sets of test items, in the form of multiple-choice questions, designed by English teachers. The data was obtained from one of the senior high school teachers in Indonesia. Each set of test items consists of 50 questions such as "What type of text is it?", "What type of text it is?", "What is evaporation?", etc. The sample of test items were randomly choosen from an Indonesia senior high school level from the grade range of 10 grader to 12 grader in the academic year of 2016 to 2019. Each academic year is represented by a set of test items that will be analyzed.

\section{Data Analyses}

After the test items were obtained, they were analyzed based on cognitive processes of LOTS and HOTS derived from Bloom's revised taxonomy. These indicators of LOTS cover some skills namely remembering, understanding and applying while the indicators of HOTS cover some skills including analyzing, evaluating, and creating. The result of the analysis was calculated in the form of percentages. The formula of the percentage is as follows.

$$
\mathrm{P}=n / \mathrm{N} \times 100 \%
$$

\footnotetext{
$\mathrm{P} \quad=$ percentage

$n \quad=$ number of questions based on the indicator found in the test items

$\mathrm{N} \quad=$ the total number of test items
}

After finding out the frequencies and types of thinking skills represented on the test items, the researchers described qualitatively the finding further.

\section{FINDINGS}


In this section, the analysis results of 4 set of test items designed by English teachers in the year of 2016, 2017, 2018, and 2019 are presented. The total of test items analyzed in this study is 200 questions with 50 questions of each set. According to the previous study, questions found on the textbook are mostly those with lower-order thinking skills (Anasy, 2016; Freahat \& Smadi, 2014; Igbaria, 2013; Raqqad \& Ismail, 2018; Razmjoo \& Kazempourfard, 2012; Ulum, 2016; Zaiturrahmi et al., 2017). Another study on national examination and teacher-made questions shows the same result (Ahmad, 2016; Ramadhana et al., 2018). Supported by the previous studies, all set of test items from 2016 to 2019 mostly represent lower-order thinking skills. To be more detailed, the number of test items and thinking skills covered is presented on table 1.

Table 1. The frequency and percentage of thinking skills represented on test items in the academic year of 2016 to 2019

\begin{tabular}{|c|c|c|c|c|c|c|c|c|c|}
\hline & \multirow[t]{3}{*}{ Cognitive Skills } & \multicolumn{8}{|c|}{ Test Item Year } \\
\hline & & \multicolumn{2}{|c|}{2016} & \multicolumn{2}{|c|}{2017} & \multicolumn{2}{|c|}{2018} & \multicolumn{2}{|c|}{2019} \\
\hline & & $n$ & $\%$ & $n$ & $\%$ & $N$ & $\%$ & $n$ & $\%$ \\
\hline \multirow{3}{*}{$\stackrel{n}{0}$} & C1 (Remember) & 3 & 6 & 1 & 2 & 1 & 2 & 0 & 0 \\
\hline & C2 (Understand) & 28 & 56 & 34 & 68 & 32 & 64 & 28 & 56 \\
\hline & C3 (Apply) & 6 & 12 & 4 & 8 & 8 & 16 & 8 & 16 \\
\hline \multirow{4}{*}{$\begin{array}{l}n \\
0 \\
0 \\
\\
\end{array}$} & C4 (Analyze) & 13 & 26 & 11 & 22 & 9 & 18 & 14 & 28 \\
\hline & C5 (Evaluate) & 0 & 0 & 0 & 0 & 0 & 0 & 0 & 0 \\
\hline & C6 (Create) & 0 & 0 & 0 & 0 & 0 & 0 & 0 & 0 \\
\hline & Total & 50 & 100 & 50 & 100 & 50 & 100 & 50 & 100 \\
\hline
\end{tabular}

Based on the table, it appears that the thinking skills which are represented on the test items are the skills of remembering, understanding, applying and analyzing. All the lower-thinking skills are covered on the test items sets. On the other hand, for higher-order thinking skills, the skill represented on the test items set is only the skill of analyzing. In the 2016 set of test items, the skill mostly used is the skill of understanding (C2) which is represented by $56 \%$. The second most used skill is the skill of analyzing with $13 \%$ while the fewer skills represented are the skills of applying and remembering which are represented by $12 \%$ and $6 \%$ out of all 50 test items. In the year 2017, the skill which is mostly represented on the test items set is the skill of understanding (C2) which shows $68 \%$ on its percentage. The second skill which mostly appears is the skill of analyzing with the percentage of $22 \%$ of all 50 questions. The least skills represented on the set of test items in the year of 2017 are the skill of applying with $8 \%$ and the skill of remembering with $2 \%$. In the year of 2018, the skill which dominates in the test items is the skill of understanding (C2), like the previous two years, with a percentage of $64 \%$. The second skill which is dominated, with a percentage of $18 \%$, is the skill of analyzing. The next skill that dominates, with a percentage of $16 \%$, is the skill of applying while the least skill which dominates is the skill of remembering with the total percentage of $2 \%$. In the year 2019, the skill which mostly appears on the test items is the skill of understanding (C2) with the total percentage of $56 \%$. The second skill which mostly appears is the skill of analyzing with $28 \%$ out of all 50 questions. The least skill which appears is the skill of applying which shows $16 \%$ in percentage.

From the table, we can conclude that although the percentage of each skill in each year is varied, the similarity is that the most skill represented on each set of test item is the skill of understanding $(\mathrm{C} 2)$, then it is followed by the skill of analyzing, applying and the least is remembering. The difference is that there is no remembering skill represented on the test items. The difference is only in the year of 2019 while in all other years it appears at the very least place. The highest percentage of remembering skill appearance is in the set of test items from the year 2016 while the very least is in the set of test items from 2019. In addition, the skill of understanding is mostly demonstrated in the test items in the year of 2017 with $68 \%$ out of all 50 questions while the skill of applying is mostly demonstrated in the test item of the year of 2018 and 2019. Last but not least, the skill of analyzing has the highest frequency on the test items of the year 2019. Finally, as shown on 
the table, the higher-order thinking skill which is covered on the test items is only the skill of analyzing while all lower-order thinking skills are all covered on the test items except on the test items in 2019. Thorough explanation and discussion of the results are presented in the next session.

\section{RESULT, DISCUSSION, AND SUGGESTIONS}

\section{C1 (Remember)}

The skill of remembering that falls under the term lower-order thinking skills is divided into some cognitive processes such as locating knowledge in long-term memory that is consistent with presented material and retrieving relevant knowledge from long-term memory (Anderson \& Krathwohl, 2001). The following table shows the cognitive processes demonstrated remembering skill on the test items.

Table 2. Cognitive Process of Remembering Skill Demonstrated on the Test Items

\begin{tabular}{lccccccc}
\hline \multicolumn{1}{c}{ Cognitive Process } & \multicolumn{4}{c}{ Frequencies } & & Test Item Examples \\
\cline { 2 - 6 } & 2016 & 2017 & 2018 & 2019 & \\
\hline $\begin{array}{l}\text { Defining a word based on } \\
\text { the text given }\end{array}$ & 1 & 0 & 0 & 0 & What is evaporation? \\
\hline Recalling a fact/elements & 2 & & 1 & 1 & 0 & $\begin{array}{l}\text { The following are the basic } \\
\text { elements of a short story, except } \\
\end{array}$ \\
\end{tabular}

The table describes the cognitive processes of the $\mathrm{C} 1$ level that occur on the test items which are defining a word based on the text given and recalling a fact or element. In the first cognitive process, the students were given a text then there was a question asking the definition of a particular word where the answer is already in the text. The example of the question is "What is evaporation?" which is firstly followed by a text explaining about raining season and what evaporation is. From the text provided, students can easily find its definition on the text by scanning the word evaporation and then match the definition of the text with the alternative answers. However, this type of question only appears once in the year 2016. The second cognitive process is recalling a fact or some elements. In this cognitive process, students are given a question that is related to the material that has been taught in the classroom that they need to recall to answer the question. The example is the question "The following are the basic elements of a short story, except ..." which demands students to recall their memory about the element of a short story that has been taught by their teacher. This type of question appears twice in 2016 test items while in 2017 and 2018 test items, it only appears once. In addition, in the year 2019, there is no such type of question appears.

\section{C2 (Understand)}

The skill of understanding that falls under the term lower-order thinking skills includes some cognitive processes such as representing, paraphrasing, categorizing, predicting, etc. (Anderson \& Krathwohl, 2001). The following table describes the cognitive processes that demonstrate remembering skills on the test items.

Table 3. Cognitive Process of Understanding Skill Demonstrated on the Test Items

\begin{tabular}{|c|c|c|c|c|c|}
\hline \multirow[t]{2}{*}{ Cognitive Process } & \multicolumn{4}{|c|}{ Frequencies } & \multirow[t]{2}{*}{ Test Item Examples } \\
\hline & 2016 & 2017 & 2018 & 2019 & \\
\hline $\begin{array}{l}\text { Finding details based on } \\
\text { text that is given }\end{array}$ & 13 & 14 & 21 & 21 & $\begin{array}{l}\text { What must we do to let the } \\
\text { skaters play? }\end{array}$ \\
\hline $\begin{array}{l}\text { Classifying } \\
\text { terms/expressions }\end{array}$ & 2 & 0 & 1 & 1 & $\begin{array}{l}\text { Which of the following options } \\
\text { contain technical terms? }\end{array}$ \\
\hline $\begin{array}{ll}\text { Finding } & \text { word } \\
\text { meaning/synonym } & \end{array}$ & 8 & 12 & 3 & 2 & $\begin{array}{l}\text { Presley was the first singer who } \\
\text { blends the rhythm-and-blues } \\
\text { style (Paragraph } 2 \text { ). The italic } \\
\text { word is synonymous with ... }\end{array}$ \\
\hline Finding & 5 & 8 & 6 & 2 & The main idea of the first \\
\hline
\end{tabular}




\begin{tabular}{lllllll}
\hline idea/idea/topic & \multicolumn{1}{c}{ paragraph is ... } \\
\hline Finding word references & 0 & 0 & 1 & 2 & $\begin{array}{l}\text { "These are soon absorbed by } \\
\text { the vill..." The underlined word } \\
\text { refers to ... }\end{array}$ \\
\hline
\end{tabular}

The table shows that the cognitive process of the C2 level occurs on the test items are four types. The first is finding details based on the text given to the students. This type of question requires students to find some details based on the text given and questions asked. For example, students are given a text about playing skateboard then given a question related to the text such as "What must we do to let the skaters play?" which can be answered when students read the text and understand the test as well as the question. This type of question appears the most of all questions. The second is classifying terms or expressions given. In this type of question, students are sometimes given a text but sometimes they are not. For example, students are given a text then given a question "Which of the following options contain technical terms?" which requires students to classify some terms based on the text. This type of question is found in the set of test items in the year 2016, 2018, and 2019. The next type is finding word meaning or synonym. Sometimes this type of question can be considered as an easy question but sometimes it can be a hard one, it depends on the understanding of the students toward the particular word given. In this case, students are provided a text to read then asked the meaning or synonym of a particular word from the text. When students have no clue about the word meaning, they usually look at the context and try to guess the meaning of the given word. The synonym question is normally followed by a context. For example, there is a sentence "Presly was the first singer who blends the rhythm-and-blues style (Paragraph 2)" then it is followed by the question "The italic word is synonymous with ...". This type of question is found mostly in the set of test items from the year 2017 with a total of 12 questions about word meaning and word synonym. Another type of cognitive process in C2 is finding the main idea, topic, or theme of a particular text. In this type of question, students are provided a text then asked about its main idea in paragraphs or its topic or theme. The example is the question "The main idea of the first paragraph is ..." which is followed by a text before the question given. To answer this question, first, the students should understand the text and conclude its main idea, topic, or theme. This type of question appears in all set of test items from 2016 to 2019 with the highest frequency is in 2017 test items. The last type is finding word reference which appears in the test items set in 2018 and 2019. Given this type of question, students require to read the provided text and understand the context to find the word reference asked. The example is firstly students provided a sentence "These are soon absorbed by the vill..." then they are asked "The underlined word refers to ..." to answer.

\section{C3 (Apply)}

The skill of applying that falls under the term lower-order thinking skills, cover some cognitive processes such as implementing a procedure to a familiar or unfamiliar task (Anderson \& Krathwohl, 2001). The following table shows the cognitive processes that demonstrate the skill of applying on the test items.

Table 4. Cognitive Process of Applying Skill Demonstrated on the Test Items

\begin{tabular}{|c|c|c|c|c|c|}
\hline \multirow[t]{2}{*}{ Cognitive Process } & \multicolumn{4}{|c|}{ Frequencies } & \multirow[t]{2}{*}{ Test Item Examples } \\
\hline & 2016 & 2017 & 2018 & 2019 & \\
\hline \multirow{2}{*}{$\begin{array}{l}\text { Applying vocabularies } \\
\text { based on grammatical } \\
\text { rules/context }\end{array}$} & 6 & 4 & 8 & 8 & $\begin{array}{l}\text { The trees would have produced } \\
\text { more fruits if you ... regularly. }\end{array}$ \\
\hline & & & & & $\begin{array}{l}\text { Pino: I must go home now. } \\
\text { Reny But it is still raining. You } \\
\ldots \text { be sick if you walk in the } \\
\text { rain. }\end{array}$ \\
\hline
\end{tabular}

The table depicts the cognitive process of the $\mathrm{C} 3$ level occurs on the test items. The cognitive process occurs on the test items is applying vocabularies based on grammatical rules and context. In this type of question, students require not only to recall their memory about grammatical rules but also to apply it on the 
sentence based on the given context. The example is fill in the blank questions about the conditional sentence "The trees would have produced more fruits if you ... regularly." To answer the question, students must know the conditional sentence and its formula, then apply it to the given sentence. All set of test items from 2016 to 2019 include this type of application-questions. The types are varied such as the questions about conditional sentences, simple past tense, simple perfect tense, etc.

\section{C4 (Analyze)}

The skill of applying that falls under the term higher-order thinking skills covers some cognitive processes such as differentiating, organizing and attributing (Anderson \& Krathwohl, 2001). The following table shows the cognitive processes that demonstrate analyzing skill on the test items.

Table 5. Cognitive Process of Analyzing Skill Demonstrated on the Test Items

\begin{tabular}{|c|c|c|c|c|c|}
\hline \multirow[t]{2}{*}{ Cognitive Process } & \multicolumn{4}{|c|}{ Frequencies } & \multirow[t]{2}{*}{ Test Item Examples } \\
\hline & 2016 & 2017 & 2018 & 2019 & \\
\hline $\begin{array}{l}\text { Concluding title/heading } \\
\text { of the given text }\end{array}$ & 2 & 0 & 0 & 0 & The best title for the story above is ... \\
\hline $\begin{array}{l}\text { Identifying the type of } \\
\text { given text }\end{array}$ & 2 & 2 & 1 & 5 & What type of text is it? \\
\hline $\begin{array}{l}\text { Identifying general } \\
\text { structure/organization of } \\
\text { the given text }\end{array}$ & 3 & 2 & 0 & 6 & The organization of the text 4 is ... \\
\hline $\begin{array}{l}\text { Identifying } \\
\text { communicative } \\
\text { purpose/goal of the given } \\
\text { text }\end{array}$ & 3 & 3 & 3 & 3 & What is the purpose of the text? \\
\hline $\begin{array}{l}\text { Arranging jumbled } \\
\text { sentences into a good } \\
\text { paragraph }\end{array}$ & 1 & 2 & 1 & 0 & $\begin{array}{l}\text { 1. So, she had to wear her old and } \\
\text { uncomfortable shoes instead. } \\
\text { 2. She was mad at everybody in her } \\
\text { home, her mom, dad and also her } \\
\text { brother. } \\
\text { 3. It is several minutes before Vina's } \\
\text { friends picked her up to go to a } \\
\text { party, but she was still busy trying to } \\
\text { find her new shoes because she } \\
\text { really wanted to wear them to the } \\
\text { party. } \\
\text { 4. When her friends reached her house, } \\
\text { she still couldn't find them. } \\
\text { 5. She even accused Dany, her brother, } \\
\text { of having hidden her shoes. } \\
\text { 6. Dany was angry with her because of } \\
\text { being accused. } \\
\text { The best arrangement of the story } \\
\text { above is ... }\end{array}$ \\
\hline $\begin{array}{ll}\begin{array}{l}\text { Analyze the } \\
\text { content/song } \\
\text { conclude }\end{array} & \begin{array}{r}\text { given } \\
\text { and }\end{array} \\
\end{array}$ & 2 & 2 & 2 & 0 & The meaning of the song above is ... \\
\hline Error analysis & 0 & 0 & 2 & 0 & $\begin{array}{l}\text { Which one is wrong? } \\
\text { Sam: "would you like to go to }\end{array}$ \\
\hline
\end{tabular}


watch movie this weekend?"

Carly: "I can't, I am low on cash

right now. What about stay at home and

E

watch TV instead.

The table shows that there are seven cognitive processes found on the test items. The first is the concluding title or heading of the given text. In this type of question, students are given a text then asked, for example, what the suitable title is for the text. To answer this type of question, students need to understand and analyze the whole content of the text and conclude what the best title is. The other types are identifying the general structure, communicative purpose, and type of text. To answer these types of questions, students need to understand and analyze the text. For example, students are given a text and given some questions such as "The organization of the text 4 is ...", "What is the purpose of the text?" or "What type of text is it?". These questions appear on the test items year 2016 to 2019 except for 2018. In the year of 2018, questions regarding general structure or text organization are not found. The next type is the arranging-sentence type of questions. Based on this question, students are given several sentences that are jumbled then they are asked to arrange it into the correct order so that it becomes a good paragraph. To answer this type of question, students need to understand the sentences first and analyze the correct order of the sentences. The arranging jumbled sentence-questions are found in all sets of test items except in the year of 2019. The next type is the question related to song analysis. In this type of questions, there will be song lyrics provided. Students require to understand the lyrics as well as the song context then conclude the meaning of the song. The example is the question "The meaning of the song above is ..." along with a song lyric provided. The last but not least is questions related to error analysis. This type of question only appears on the test items in the year 2018.

\section{CONCLUSION}

Regarding thinking skills represented on the test items designed by English teachers, it is revealed that lower-order thinking skills covering the skill of remembering, understanding, and applying dominates compared to the higher-order thinking skills. Obviously, in the level of higher-order thinking skills, there is only the skill of analyzing represented on the test items while the skills of evaluating and creating are not found. Out of all six skills of Bloom's revised taxonomy, the questions regarding understanding skill are on the top as it is found that more than $50 \%$ of the questions on the test item sets from 2016 to 2019 are understanding-based questions, the rest are analyzing-based questions, applying-based questions, and remembering-based questions. In addition, it is suggested that the future studies will examine senior high school teachers' understanding regarding higher-order thinking skills that will be one of some factors in the practice of designing HOTS-based test items. Furthermore, it is also suggested that in the near future, an evaluation is needed to evaluate the test items made since the proportion of lower-order thinking skills as well as higher-order thinking skills are not proportional and whether those test items can be sufficient to promote higher-order thinking skills to the students of senior high schools in Indonesia context.

\section{REFERENCES}

Ahmad, U. L. (2016). Senior high school english national examination and thinking skills. Beyond Words, 4(2), 168-190. Retrieved from http://journal.wima.ac.id/indexed.php/BW\%0AReferences

Akin, A., Hamedoglu, M. A., Arslan, S., Akin, Ü., Celik, E., Kaya, Ç., \& Arslan, N. (2015). The adaptation and validation of the turkish version of the critical thinking disposition scale ( CTDS ). Educational Research Association: The International Journal of Educational Researchers, 6(1), 31-35.

Alzu'bi, M. A. (2014). The extend of adaptation bloom's taxonomy of cognitive domain in english questions included in general secondary exams. Advances in Language and Literary Studies, 5(2), 2-7. 
https://doi.org/10.7575/aiac.alls.v.5n.2p.67

Anasy, Z. (2016). HOTS (Higher Order Thinking Skills) in reading exercise. Tarbiya: Journal of Education in Muslim Society, 3(1), 51-63. https://doi.org/10.15408/tjems.v3il.3886

Anderson, L., \& Krathwohl, D. (2001). A taxonomy for learning, teaching, and assessing. New York: Longman.

Ary, D., Jacobs, L. C., Irvine, C. K. S., \& Walker, D. (2010). Introduction to research in education (eight). Cengage Learning.

Assare, Mohammadi, Forutan, \& Salehizadeh. (2016). The impact of globalization on education. Journal of Administrative Management, Education, and Training, 12(5), 27-33. https://doi.org/10.25034/ijcua.2018.4707

Asysyifa, D. S., Jumaidi, J., Wilujeng, I., \& Kuswanto, H. (2019). Analysis of students critical thinking skills using partial credit models ( PCM ) in physics learning. International Journal of Educational Research Review (IJERE), 4(2), 245-253.

Brookhart, S. M. (2010). How to assess higher-order thinking skills in your classroom. Alexandria: ASCD.

Conklin, W. (2012). Higher-order thinking skills to develop 21st century learners. Shell Educational Publishing, Inc. Retrieved from http://www.shelleducation.com

Council, N. R. (2013). Education for life and work: Developing transferable knowledge and skills in the 21st century. Washington DC: National Academies Press.

Duman,T. \& Karagoz,S. (2016). An evaluation of Turkish teacher education system compared to other models in different countries. International Journal of Educational Research Review, 1 (1), 1-13

Freahat, N. M., \& Smadi, O. M. (2014). Lower-order and higher-order reading questions in secondary and university level efl textbooks in Jordan. Theory and Practice in Language Studies, 4(9), 1804-1813. https://doi.org/10.4304/tpls.4.9.1804-1813

Igbaria, A. K. (2013). A Content Analysis of the wh-questions in the efl textbook of horizons. International Education Studies, 6(7), 200-224. https://doi.org/10.5539/ies.v6n7p200

Khan, W. B., \& Inamullah, H. M. (2011). A study of lower-order and higher-order questions at secondary level. Asian Social Science, 7(9), 149-157. https://doi.org/10.5539/ass.v7n9p149

Lewis, A., \& Smith, D. (2009). Defining higher order thinking, (March 2015), 37-41. https://doi.org/10.1080/00405849309543588

Mulyanto, H., Gunarhadi, G., \& Indriayu, M. (2018). The effect of problem based learning model on student mathematics learning outcomes viewed from critical thinking skills. International Journal of Educational Research Review (IJERE), 3(2), 37-45.

Nastasi, B., \& Clements, D. (1987). Social-cognitıve behaviors and higher-order thinking in educational computer environments. Learning and Instruction, 2, 215-238.

Partnership for 21st Century Skills (P21) (2015). Framework for 21st Century Learning.

Pogrow, S. (1988). Teaching thinking to at-risk elementary students. Educational Leadership, (79-85).

Ramadhana, N. A., Rozimela, Y., \& Fitrawati. (n.d.). High order thinking skills-based questions in the test 1tems developed by senior high school english teachers of Padang. Journal of English Language Teaching, $7(4), 720-731$.

Raqqad, Y. Al, \& Ismail, H. H. (2018). Analyzing the reading questions of ap12 textbook according to analyzing the reading questions of ap12 textbook according to Bloom's taxonomy. International Journal 
of Education, Psychology and Counseling, 3(22), 84-94.

Razmjoo, S. A., \& Kazempourfard, E. (2012). On the representation of Bloom's revised taxonomy in interchange coursebooks. The Journal of Teaching Language Skills, 4(1), 171-204.

Setyarini, S., \& Ling, M. A. (2019). Promoting higher order thinking skills in storytelling for teaching english to young adolescents in 21st century. International Seminar on Language, Education, and Culture, 2019, 155-164. https://doi.org/10.18502/kss.v3i10.3897

Ulum, O. G. (2016). A descriptive content analysis of the extent of Bloom's taxonomy in the reading comprehension questions of the course book q : Skills for Success 4 Reading and Writing A Descriptive Content Analysis of the Extent of Bloom 's Taxonomy in the. The Qualitative Report, 21(9), 1674-1683. Retrieved from http://nsuworks.nova.edu/tqr/vol21/iss9/7

Zaiturrahmi, Kasi, U., \& Zulfikar, T. (2017). ANALYSIS OF INSTRUCTIONAL QUESTIONS IN AN ENGLISH TEXTBOOK FOR SENIOR HIGH SCHOOLS. English Education Journal, 8(4), 536-552.

Zohar, A. (2006). The Nature and Development of Teachers ' Metastrategic Knowledge in the Context of Teaching Higher Order Thinking. Journal of the Learning Sciences, 15(3), 331-377. https://doi.org/10.1207/s15327809jls1503_2 